\title{
The Implementation Strategies of Cultivating Socialist Core Values in College English Teaching
}

\author{
Yi Yang \\ Baoding College, Baoding, China \\ Email: same512@163.com
}

How to cite this paper: Yang, Y. (2018). The Implementation Strategies of Cultivating Socialist Core Values in College English Teaching. Creative Education, 9, 1829-1834. https://doi.org/10.4236/ce.2018.912133

Received: August 20, 2018

Accepted: September 15, 2018

Published: September 18, 2018

Copyright $\odot 2018$ by author and Scientific Research Publishing Inc. This work is licensed under the Creative Commons Attribution International License (CC BY 4.0).

http://creativecommons.org/licenses/by/4.0/

\begin{abstract}
To cultivate socialist core values in college English, teaching possesses certain academic advantages and practical conditions. In college English teaching activities, we should try to strengthen the socialist core values education through the following approaches: first, optimization of teachers; second, explore the values contained in the textbooks and integrate them into the core socialist values; third, keep close contact with social hotspots and expand the channels of education in college English teaching; fourth, construct education mode combining explicit and implicit education; finally, reform the traditional evaluation model, establish a perfect evaluation system.
\end{abstract}

\section{Keywords}

Socialist Core Values, College English Teaching, Implementation Strategies

\section{Introduction}

The 18th National Congress of the Communist Party of China clearly put forward "advocating prosperity, democracy, civilization and harmony, advocating freedom, equality, justice and the rule of law; advocating patriotism, dedication, integrity and friendship, and actively cultivating and practicing socialist core values". Socialist core values are the socialist ideology and culture, ideology, morality, are the national spirit of socialism, the social concept and abstract generalization of citizen morals (O'Malley \& Chamot, 2010). In the process of actively cultivating and practicing the socialist core values, higher schools not only need to play a role of main channel and position in the ideological and political theory course, but also need to dig more specialized courses teaching guiding role in the socialist core values education (Stern, 2016). College English teaching, 
whether English major teaching or public English teaching, is of great significance and has unique advantages in the socialist core values education.

\section{Feasibility of Socialist Core Values Education}

Integrating socialist core values education into college English teaching conforms to the law of ideological and political education work of college students. Both English major teaching and public English teaching have their unique advantages and practical conditions to develop socialist core values education. Therefore, it is feasible to integrate socialist core values education into college English teaching.

1) The necessity of integrating socialist core values education into college English teaching

From the perspective of social psychology, socialist core values are "the internal concepts formed by individuals on socialist values, value system and core value system, which are an attitude in essence, whose cultivation needs to go through two stages of identification and internalization" (Brown, 2013). To promote college students' recognition and internalization of socialist core values, single theoretical indoctrination is not suitable for college students' cognitive and emotional needs, which should combine with infiltration of education. Infiltration of education is a concept corresponding to indoctrination of education. As the implicit way of ideological and political education work, it supplements the dominant education (that is, indoctrination of education). Educators, taking the education purpose kneading in the specific subject knowledge, in imperceptible way to pass to the educated "the core idea is to emphasize teaching in a silent and refreshment way" (Littlewood, 2010). The socialist core values embody people's common pursuit of the good deeds and good ideals. In the process of college English teaching, teachers should combine the values and norms of behavior advocated by socialist core values with the relevant teaching contents and learning activities, which can contact closely with students' study and life reality, so as to improve college students' rational recognition on the socialist core values and emotional resonance. Therefore, it is beneficial to realize the recognition and internalization of socialist core values.

2) The discipline advantage of integrating socialist core values education into college English teaching

English teaching in colleges and universities, no matter English major teaching or English teaching as a public class, has the discipline characteristic to be advantageous to develop the socialist core value education. First of all, education has the features of human education, which is consistent with the core socialist values education. According to the rule of human education, a variety of teaching modes and methods such as situational teaching, case teaching and interactive teaching are used comprehensively. Teachers should apply research achievements in teaching practice and pay attention to improving teaching efficiency. Secondly, English teaching is not only the learning and teaching of language knowledge 
and language skills, but also the introduction and review of western social ideology and culture represented by British national culture. In the conflict with different values in western society, socialist core values better reflect their applicability and recognition in the international community with their inclusiveness and epochal nature, so it is easier for students to deeply understand and highly identify with socialist core values. Thirdly, in the process of learning English and cultural knowledge system, students are exposed to the language material contents, thoughts, which are targeted to lead to the topics, such as the personal character and morality, society and the nation's healthy development, etc, and help to guide students to more detailed understanding of the socialist core values. In the practice and application of language skills, a certain content of socialist core value can be taken as the main idea and integrated into the teaching practice in and out of classes such as situational dialogue, translation practice, English speech or writing, and even social practice, which is helpful for students to consciously practice socialist core values.

\section{Implementation Strategies of Integrating Socialist Core Values Education in College English Teaching}

In college English teaching, carrying out the socialist core values education is the extension and supplement of the socialist core values education to the idea of political theory class teaching, which is mainly in the form of infiltration education in the process of implementation of the socialist core values into the English teaching content and teaching activities inside and outside, so that the students can identity and practice the socialist core values to achieve the effect of propaganda and foster students in silence.

College English teaching should regard students' English communication ability as the main line, their moral cultivation as the goal, search the fit between students' personal accomplishment and the social development. In college English teaching activities, we should try to strengthen the socialist core values education through the following approaches: first, optimization of teachers, strengthen the consciousness of English teachers of socialist core values education; second, we should fully explore the values contained in the textbooks and integrate them into the core socialist values; third, we should keep close contact with social hotspots and expand the channels of education in college English teaching; fourth, multiple education methods should be used to construct education mode combining explicit and implicit education (Lewis, 2009); finally, reform the traditional evaluation model, establish a perfect evaluation system, and encourage teachers to actively explore the specific ways to strengthen the socialist core values education in college English teaching.

1) Strengthen the awareness of teachers' socialist core values education

There is no doubt that the teacher has a decisive influence on the growth of the students; English teachers' values have a subtle influence on students. So teachers should improve their own professional skills, at the same time they need 
to constantly improve their own moral accomplishment and culture, with their own personality charm and learning affecting students.

The research direction of college English teachers is mainly in English education, linguistics, British and American literature and other aspects related to English, and they lack sufficient awareness and experience of values education of college students. English teachers are not only the interpreters of English knowledge, but also the communicators of culture, shouldering the dual responsibility of teaching and educating people. Teachers have the responsibility to deeply understand students' learning and life, listen to their hearts, fully grasp their thinking dynamics, and strive to build a democratic, equal and harmonious teacher-student relationship. Colleges and universities can optimize the ranks of teachers through activities such as "taking the old with the new", strengthen leading role by example, improve the ability of young teachers to educate, and establish a good image of teachers.

2) Explore the values contained in the textbook education

The college English teaching materials are mostly based on the original books of Britain and the United States and other countries, with rich contents and distinct unit themes. Teachers should combine the cultural background knowledge contained in the text with efforts to explore the values behind the cultural phenomena, and conduct socialist core values for students. For example, when learning about the themes such as "Society", "environment", "Spirits", etc, teachers consciously advocate the core socialist values of "democracy, civilization, harmony, freedom, equality, justice, rule of law" to students. Teachers can carry out socialist core values of "patriotism, dedication, integrity and friendliness" when they are learning themed texts related to careers and individuals such as "Career", "Friendship" and "Family" (Pan, 2011).

English teaching should not only guide students to understand western culture and ideas, but also cultivate their love and confidence in local culture. Chairman Xi Jinping stressed in the 19th party report that we should strengthen cultural confidence and promote the prosperity of socialist culture. Therefore, teachers should cultivate students' cultural confidence with a high sense of responsibility, pay attention to the combination of cultural elements in the language, guide students to treat different cultures correctly, avoid blindly worshiping foreign things, arouse students' interest in understanding the profound connotation of Chinese culture, and enhance their national pride.

3) Expand the channels of socialist core values education in English teaching

In college English teaching, teachers should combine the abstract values education with social hot spots, guide students to focus on current affairs, expand channels of socialist values education in English teaching, deepen students' understanding of socialist core values and experience, integrate the ideological education silently into English study, cause the students to think of various kinds of social phenomenon. When choosing to expand channels, teachers should be as close to students' life as possible, pay attention to their interesting points, and 
provide students with learning situations they are willing to accept.

For example, when the 19th CPC national congress is held, teachers can guide students to strengthen the 19th CPC spirit through learning English, organize students to discuss how to tell foreign friends about China's brilliant achievements and take pride in China's rise. We should keep our original aspiration and keep our mission firmly in mind, and hold high the banner of socialism with Chinese characteristics. Organize students to discuss the topics they are interested in, such as "Lucid waters and lush mountains are invaluable assets", and "You should ride the waves of your day". Organize students to set up the "19th party English column", striving to create a bilingual learning atmosphere while carrying out socialist core values education.

4) Construct education mode combining explicit and implicit education

In the process of socialist core value education, if the education method adopted is improper, it will directly affect the teaching effect of English class, and it is not conducive to education of values. Therefore, in college English teaching, teachers should follow the rules of language learning, carry out the socialist core values education with explicit and implicit combining education mode according to the characteristics of college students, and guide college students to acquire autonomous education experience from non-cognitive psychology.

College English teachers should constantly update teaching content, reform and innovate teaching methods, explore the lively classroom teaching mode, make full use of multimedia and internet, build a communication platform between teachers and students; for example, establish wechat group, QQ group, expand the education time and space of college students, guide students to build correct values. Teachers should adopt the teaching methods which students are interested in, carry out a variety of values education theme activities, build open and interactive English learning atmosphere, for example, teachers can design task, encourage students to interpret socialism with Chinese characteristics in English, organize students to introduce the Chinese elements reflecting the national dignity or organize English debating competition, English speech and appreciating classical poems translation activities. These implicit educations avoid empty preaching, make the student imperceptibly accept socialistic core value education in the process of language learning, gradually and consciously internalize into moral character, outwardly show in behavior.

5) Establish a sound evaluation system

Reform the traditional evaluation mode and establish a perfect evaluation system. In the top-level design of college English teaching evaluation model, it is focused on the following aspects: students' ideological and moral indicators; the diversity of evaluation subjects; the integration of evaluation contents and the diversity of evaluation methods. In view of the evaluation of English teachers, the original single evaluation model is broken, and teachers' ethics and teaching attitude are emphasized. 


\section{Conclusion}

To sum up, college English classes are an important front for the development of socialist core values education. Throughout the top-level design of college English teaching, it is required to strengthen the socialist core values education, which demands the college English teachers to improve their comprehensive quality, explore and use different teaching strategies and methods, improve students' ability to use language through the organization of rich and colorful activities inside and outside class, at the same time, pay attention to using the theory of socialism with Chinese characteristics and socialist core values to guide and arm college students, give full play to the educational role of English teaching. In near future, the teaching mode integrating culture and values is the inevitable developing trend of English teaching, which can improve the ideological and moral cultivation of college students, promote their all-round development, contribute to promoting the dissemination of socialist core values to foreign countries, and enhance China's influence in the world.

\section{Funding}

The thesis is the research result of the social science development research project of Hebei Province: Study on the Strategies of Practicing Socialist Core Values in the Textbook Construction of English Teaching Theory and Practice. Project number: 201803040129.

\section{Conflicts of Interest}

The authors declare no conflicts of interest regarding the publication of this paper.

\section{References}

Brown, H. D. (2013). Principles of Language Learning and Teaching. New York: Prentice Hall.

Lewis, M. (2009). How to Study Foreign Languages. New York: Palgrave.

Littlewood, W. (2010). Communicative Language Teaching. London: Cambridge University Press.

O’Malley, J. M., \& Chamot, A. U. (2010). Learning Strategies in Second Language Acquisition. London: Cambridge University Press.

Pan, M. W. (2011). Communicative Competence from the Perspective of Multimodal: Reconstruction and Exploration. Shanghai: Shanghai Foreign Studies University.

Stern, H. H. (2016). Fundamental Concepts of Language Teaching. Oxford: Oxford University Press. 